\title{
Policy and Management of Medical Devices for the Public Health Care Sector in Benin
}

\author{
P. Th. Houngbo1,3, G. J. v. d. Wilt', D. Medenou², \\ L. Y. Dakpanon ${ }^{1,2}$, J. Bunders ${ }^{3}$ and J. Ruitenberg ${ }^{3}$ \\ ${ }^{1}$ Ministry of Health, \\ ${ }^{2}$ Polytechnic School, University of Abomey-Calavi, \\ ${ }^{3}$ Athena Institute, Vrije Universiteit, Amsterdam, \\ 1,2Republic of Benin \\ ${ }^{3}$ The Netherlands
}

\section{Introduction}

Health technology, according to WHO is the application of organized knowledge and skills in the form of devices, medicine, vaccines, procedures and systems development to solve a health problem and improve quality of lives ${ }^{4}$. When used in this paper, the term healthcare technology means the different types of devices or equipment used in health facilities. Its encompasses: medical equipment for clinical use; hospital furniture; vehicles; service Supplies; plant; communication equipment; fire fighting equipment; fixtures built into the building; office equipment; office furniture; training equipment, walking aids and workshop equipment.

Healthcare technologies offer many benefits and have greatly enhanced the ability of health professionals to prevent, diagnose and treat diseases ${ }^{11}$. They are one of the essential elements for the delivery of health services. The use of technology in health care systems in developing and transition countries faces a great number of difficulties. Since about $95 \%$ of the healthcare technology used in these countries is imported ${ }^{30}$; mismatches occur because the technology development process has not usually considered the needs and realities of the target environments. These mismatches in the technology transfer process to countries with financial and technical constraints are often of great significance. Thus, in Benin, medical devices and equipment represent a significant proportion of national health care expenditure. Each year, more than 10,600,000 US\$, (about 20\%) ${ }^{20}$ of the national health budget, are spent on procurement of medical devices and equipment for healthcare facilities. Despite this great amount of money spent each year on an ever-increasing array of medical devices and equipment, not enough attention is paid to the equipment use and maintenance. Management of medical devices is not yet recognised as an integral part of public health policy. Planning, follow up and maintenance of the equipment are inefficient and ineffective $12,13,14,15,16,17,18,19,20$, and 21 . 
This study, supported by the Netherlands Organisation for International Cooperation in Higher Education (NUFFIC) from 2007 was conducted in Benin Ministry of Health (MoH) and at the University of Abomey-Calavi in collaboration with the Athena Institute, Vrije Universiteit Amsterdam from 2006-2008 aimed to identify factors appearing between 1998 and 2008 that adversely affected the healthcare technology management cycle i.e., planning, budgeting, selection, procurement, distribution, installation, training, operation, maintenance and disposal of medical devices. The results will allow to identify the key factors of mismanagement and critical maintenance system of medical devices in Benin and to formulate recommendations to improve the system. The first part of this paper gives background information on the country, its health system and an overview of its healthcare technology management state. The second part describes the methods and materials used and the third part presents the results, followed by discussion, comments and recommendations in the final section.

\section{Background information}

\subsection{Benin: The country}

Located on the West coast of Africa, the Republic of Benin is small (114,763 square kilometers), with a coastline on the Gulf of Guinea nestled between Nigeria, Niger, Burkina Faso, and Togo (Figure 1). The population, estimated at 7,839,914 in 2006, includes a multitude of ethnic and linguistic groups. Benin remains one of the world's least developed countries and has been ranked 163 of 177 on the United Nations Human Development Index (2005). Demographic and health indicators are given below (Table 1).

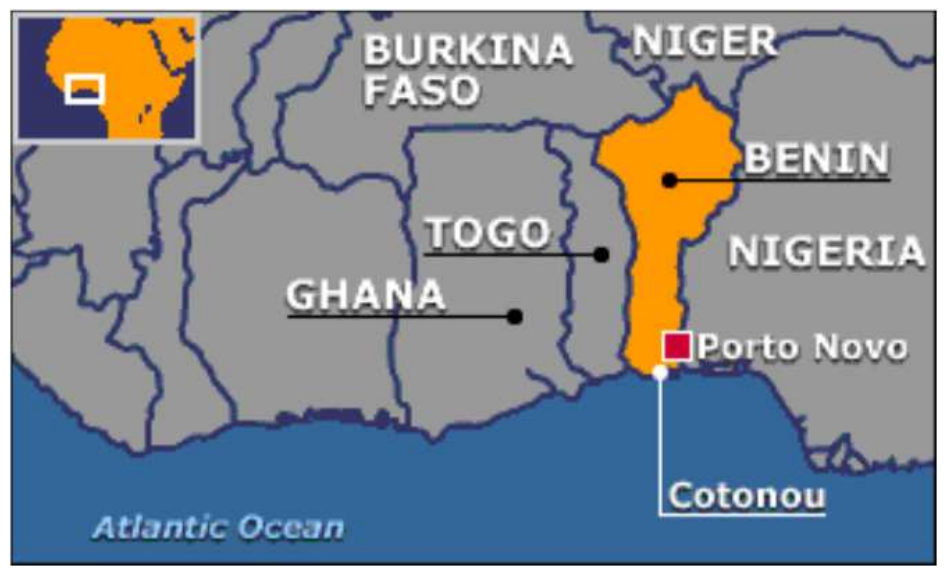

Fig. 1. Map of Benin (Source: USAID, 2006) 


\section{Indicators}

$\begin{array}{ll}\text { Population in 2006 } & 7,839,914 \\ \text { Human Development Index } & 0.437 \\ \text { Country rank } & 163 / 177 \\ \text { GPD per capita (Purchasing Power Parity US\$) } & 1,141 \\ \text { Life expectancy at birth (years) } & 55.4 \\ \text { Public expenditure on health (\% of GPD) in 2004 } & 4.5 \\ \text { Health expenditure per capita (PPP US\$) in 2004 } & 40 \\ \text { Infant mortality rate per 1,000 live births } & 67 \\ \text { Maternal mortality ratio per 100,000 live births } & 474 \\ \text { HIV/AIDS prevalence (\%) } & 2.0 \\ \text { Adult literacy rate (\% ages 15 and older) } & 34.7\end{array}$

Sources: 1. Human Development Reports: 2007/2008;

2. Benin Demographic and Health Survey 2006;

3. Benin Health Statistics Directory 2006.

Table 1. Selected demographic and health indicators of Benin

\subsection{The health system}

The public healthcare system of the country has been reorganized according to the decentralization policy and consists of three levels: central with the National Referral Hospital (> 600 beds), intermediate with five Province or Departmental Hospitals $(>100$ beds) and peripheral with thirty four Health Zones, twenty seven fairly functional Zone Hospitals ( $>46$ beds), seventy seven Communal Health Centers, four hundred eighty seven Arrondissement Health Centers and many Village Health Units and other private health facilities. Apart from that, the health system also has the following public hospitals: the Mother and Child Hospital, many detection and treatment centers for tuberculosis and leprosy, the National Hospital for Psychiatry, the National Hospital for Gerontology, two Buruli Ulceration Treatment Centers ${ }^{12}$ etc...

\subsection{Healthcare technology management and maintenance}

Healthcare technology management and maintenance remains one of the main challenges of the developing countries healthcare systems in general and, of Benin particularly. Thus, although many financial resources are used for procurement of devices, not enough attention is paid to their future. While some of the equipment were donated, a significant portion was purchased with loans provided by bilateral and multilateral agencies and will have to be paid back with great sacrifice ${ }^{26}$. One of the root causes of the equipment idleness is the lack of effective management. It is important to point out that despite the several initiatives undertaken by the ministry of health to improve the healthcare technology management cycle no significant changes have been noticed $13,14,15,16$ and 17 .

Many facilities, especially Zone Hospitals, continue to lack the basic technologies they need to provide quality care to the patients, because equipment is unavailable, inoperative, misused or inappropriate. The situation is most severe in the Communal and Arrondissement health facilities far from the first referral hospitals. This has far-reaching implications for the prevention and treatment of disease and disability and often leads to a waste of scarce resources. 


\section{Materials and methods}

The study was carried out in the $\mathrm{MoH}, 321$ healthcare facilities of the southern part of the country, the Ministry of Economy and Finance, some representatives of external support agencies in Benin and ten accredited suppliers of medical device companies. It consisted of surveys undertaken in 2006 and 2007 and of desk research (content analysis) based on 1998 to 2008 procurement collected data. It aimed to determine the factors that adversely affect the healthcare technology management cycle (planning, budgeting, selection, procurement, distribution, installation, training, operation, maintenance and disposal of medical devices) in Benin.

\subsection{Desk research and short survey}

This study focused on the procurement management of medical devices in the Republic of Benin and aimed to identify the main weak points in the procurement management system of medical devices from 1998 to 2008. It was based on data collected from documents (such as national procurement magazines and health equipment public procurement and bidding contracts from the Ministries of Health and Economy and Finances), and on interviews and informal discussions with ten local accredited suppliers of medical devices in Benin.

A comparative study was done concerning the selling prices of ten medical devices procured by Benin $\mathrm{MoH}$ further to international tenders. The steps were i) Ten medical devices were selected from the available essential medical device list. ii) Their mean reference selling prices (based on their specifications) were determined from 10 local medical device accredited suppliers based on the prices the devices were sold to the private health facilities. iii) The mean prices at which the same devices were sold to the Ministry of Health following open tenders public procurement were identified, in three periods: 1998 to 1999; 2001 to 2004 and 2005 to 2008 when the procurement evaluation process has been changed and improved. iv) The mean prices at which they were sold to the $\mathrm{MoH}$ were compared to the ad hoc mean reference selling prices provided by the private healthcare facilities and/or from the local suppliers' price list for private facilities.

\subsection{Surveys}

Two surveys were carried out in 321 healthcare facilities of the six southern departments (provinces). The first, entitled "management and maintenance of healthcare technology", was conducted in 2006 in 11 health centers and hospitals. It aimed to identify the weaknesses in the healthcare technology management and maintenance system in order to make recommendations for its improvement. Data were collected through observational visits, interviews and questionnaires. The second, entitled "healthcare technology assessment in the southern Benin public healthcare facilities" was carried out in 310 health centers and hospitals in 2006 and 2007. The first objective was to determine the extent of disparity between what medical devices/equipment were planned and what was actually available in each selected health facility to facilitate procurement for the poorly equipped health facilities of the essential medical devices. The second objective 
was to identify weaknesses in the whole Benin healthcare technology management cycle. Data were collected through observational visits and reading reports, interviews, and questionnaires (inventory sheets). The steps were i) Equipment inventory was done at all the public healthcare facilities in southern Benin; ii) Healthcare equipment in these facilities were compared to the MoH available Essential Medical Device List of each health facility level iii) The needs assessment of each healthcare facility was done using a pilot asset assessment software. Finally, interviews were held with a range of stakeholders including policy makers of the $\mathrm{MoH}$, healthcare facility managers, equipment users (physicians, nurses, midwives, lab technicians, X-ray machine technician ....) and, maintenance technicians.

\section{Results}

The results of the study are summarised in tables 2 to 6 and figure2. Tables 2, 3 and 4 show the mean ad hoc reference selling prices of selected medical devices in comparison with the prices the same devices were sold to the Ministry of Health from 1998 to 1999, 2001 to 2004 and 2005 to 2008. Table 5 and figure 2 show the trends of $[\mathrm{MoH}$ device acquisition prices/Ad hoc device reference selling prices] ratio during the three periods of years. The ten equipment studied were: 1) blood pressure device 2) spectrophotometer 3) electric suction unit 4-) Electrocardio-graph 5) X-ray apparatus 6) hot air sterilizer 7) autoclave 8) ventilator 9) anaesthesia system and 10) blood bank refrigerator.

The letter $\mathrm{X}$ that may be $\mathrm{a}, \mathrm{b}, \mathrm{c}, \mathrm{d}, \mathrm{e}, \mathrm{f}, \mathrm{g}, \mathrm{h}$, $\mathrm{i}$ or $\mathrm{j}$ represents respectively the "ad hoc reference prices" (the private healthcare facilities device acquisition prices) of each device in local currency. The letter $\mathrm{Y}$ that may be A, B, C, D, E, F, G, H, I or J are respectively the $\mathrm{MoH}$ same device acquisition prices through public procurement. Table 6 presents the findings of the two surveys and shows the factors affecting the healthcare technology management cycle in 321 health centers and hospitals in southern Benin. The factors were grouped (but not ranked) in sixth categories which were respectively maintenance and repair; distribution; use; technology assessment; policy, planning and budgeting; and procurement.

The key factors that have been identified so far include the high acquisition costs; the lack of insight of the government on medical device market prices, the lack of capacity to monitor reasonable prices from suppliers, the lack of insight into the cost/performance ratio of various brands of medical devices, an unequal distribution of devices among health care facilities, an unbalanced allocation of resources to acquisition of devices compared to infrastructure, and maintenance. Other key factors identified included the insufficiency of human resources with appropriate capacity to manage equipment, the unavailability of spare parts, and the lack of an annual maintenance budget. In a nutshell, the lack of policy and management tools like "the up to date essential medical devices list and "the reference prices list for essential medical devices" to support the implementation of the existing policy. The latter allows health sector authorities to monitor financial diversions occurring in public procurement contract awards, while the former serves as a reference tool to assess availability of fully operational devices at different hierarchical levels of healthcare facilities. 


\subsection{Findings of the desk research and short survey}

\begin{tabular}{llll}
\hline \multicolumn{1}{c}{ Devices } & $\begin{array}{l}\text { Ad hoc reference prices } \\
\text { (Private healthare facilities } \\
\text { same device acquisition prices) }\end{array}$ & $\begin{array}{l}\text { MoH device acquistition } \\
\text { prices through public } \\
\text { procurement } \\
\mathrm{Y}\end{array}$ & $\begin{array}{l}\text { YIX } \\
\text { Ratio }\end{array}$ \\
\hline 1. Blood pressure device & $\mathrm{X}$ & $\mathrm{A}=3.13 \mathrm{a}$ & 3.13 \\
2. Spectrophotometer & $\mathrm{a}$ & $\mathrm{B}=4.00 \mathrm{~b}$ & 4.00 \\
3. Electric suction unit & $\mathrm{b}$ & $\mathrm{C}=2.85 \mathrm{c}$ & 2.85 \\
4. Electrocardio-graph & $\mathrm{c}$ & $\mathrm{D}=2.38 \mathrm{~d}$ & 2.38 \\
5. X-ray apparatus & $\mathrm{d}$ & $\mathrm{E}=2.12 \mathrm{e}$ & 2.12 \\
6. Hot air sterilizer & $\mathrm{e}$ & $\mathrm{F}=2.38 \mathrm{f}$ & 2.38 \\
7. Autoclave & $\mathrm{f}$ & $\mathrm{G}=2.22 \mathrm{~g}$ & 2.22 \\
8. Ventilator & $\mathrm{g}$ & $\mathrm{H}=2.85 \mathrm{~h}$ & 2.85 \\
9. Anaesthesia system & $\mathrm{h}$ & $\mathrm{I}=3.33 \mathrm{i}$ & 3.33 \\
10.Blood bank refrigerator & $\mathrm{i}$ & $\mathrm{J}=2.32 \mathrm{j}$ & 2.32 \\
Arithmetic mean of $\mathbf{Y} / \mathbf{X}$ ratio $=$ & $\mathrm{j}$ & & $\mathbf{2 . 7 5}$ \\
\hline
\end{tabular}

Table 2. Comparison of the mean ad hoc reference prices of medical devices to the Ministry of Health same device acquisition prices, 1998 to 1999.

\begin{tabular}{lcll}
\hline \multicolumn{1}{c}{ Devices } & $\begin{array}{l}\text { Ad hoc reference prices } \\
\text { (Private healthare facilities } \\
\text { same device acquisition prices) } \\
\text { X }\end{array}$ & $\begin{array}{l}\text { MoH device acquisition } \\
\text { prices through public } \\
\text { procurement } \\
\text { Y }\end{array}$ & $\begin{array}{c}\text { Y/X } \\
\text { Ratio }\end{array}$ \\
\hline 1. Blood pressure device & $\mathrm{a}$ & $\mathrm{A}=6.66 \mathrm{a}$ & 6.66 \\
2. Spectrophotometer & $\mathrm{b}$ & $\mathrm{B}=5.55 \mathrm{~b}$ & 5.55 \\
3. Electric suction unit & $\mathrm{c}$ & $\mathrm{C}=6.66 \mathrm{c}$ & 6.66 \\
4. Electrocardio-graph & $\mathrm{d}$ & $\mathrm{D}=4.00 \mathrm{~d}$ & 4.00 \\
5. X-ray apparatus & $\mathrm{e}$ & $\mathrm{E}=3.13 \mathrm{e}$ & 3.13 \\
6. Hot air sterilizer & $\mathrm{f}$ & $\mathrm{F}=2.63 \mathrm{f}$ & 2.63 \\
7. Autoclave & $\mathrm{g}$ & $\mathrm{G}=5.00 \mathrm{~g}$ & 5.00 \\
8. Ventilator & $\mathrm{h}$ & $\mathrm{H}=4.00 \mathrm{~h}$ & 4.00 \\
9. Anaesthesia system & $\mathrm{i}$ & $\mathrm{I}=4.34 \mathrm{i}$ & 4.34 \\
10.Blood bank refrigerator & $\mathrm{j}$ & $\mathrm{J}=3.03 \mathrm{j}$ & 3.03 \\
Arithmetic mean of $\mathrm{Y} / \mathbf{X}$ ratio $=$ & & & 4.50 \\
\hline
\end{tabular}

Table 3. Comparison of the mean ad hoc reference prices of medical devices to the Ministry of Health same device acquisition prices, 2001 to 2004.

\begin{tabular}{llll}
\hline \multicolumn{1}{c}{ Devices } & $\begin{array}{l}\text { Ad hoc reference prices } \\
\text { (Private healthcare facilities } \\
\text { same device acquisition prices) } \\
\text { X }\end{array}$ & $\begin{array}{l}\text { MoH device acquisition } \\
\text { prices through public } \\
\text { procurement } \\
\text { Y }\end{array}$ & $\begin{array}{l}\text { Y/X } \\
\text { Ratio }\end{array}$ \\
\hline 1. Blood pressure device & $\mathrm{a}$ & $\mathrm{A}=2.38 \mathrm{a}$ & 2.38 \\
2. Spectrophotometer & $\mathrm{b}$ & $\mathrm{B}=3.33 \mathrm{~b}$ & 3.33 \\
3. Electric suction unit & $\mathrm{c}$ & $\mathrm{C}=2.38 \mathrm{c}$ & 2.38 \\
4. Electrocardio-graph & $\mathrm{d}$ & $\mathrm{D}=2.25 \mathrm{~d}$ & 2.25 \\
5. X-ray apparatus & $\mathrm{e}$ & $\mathrm{E}=2.22 \mathrm{e}$ & 2.22 \\
6. Hot air sterilizer & $\mathrm{f}$ & $\mathrm{F}=2.38 \mathrm{f}$ & 2.38 \\
7. Autoclave & $\mathrm{g}$ & $\mathrm{G}=2.38 \mathrm{~g}$ & 2.38 \\
8. Ventilator & $\mathrm{h}$ & $\mathrm{H}=2.63 \mathrm{~h}$ & 2.63 \\
9. Anaesthesia system & $\mathrm{i}$ & $\mathrm{I}=2.85 \mathrm{i}$ & 2.85 \\
10.Blood bank refrigerator & $\mathrm{j}$ & $\mathrm{J}=2.08 \mathrm{j}$ & 2.08 \\
Arithmetic mean of $\mathbf{Y} / \mathbf{X}$ ratio $=$ & & & 2.48 \\
\hline
\end{tabular}

Table 4. Comparison of the mean ad hoc reference prices of medical devices to the Ministry of Health same device acquisition prices, 2005 to 2008. 


\begin{tabular}{llll}
\hline \multicolumn{1}{c}{ Devices } & $\begin{array}{l}\text { Y/X ratio } \\
(1998-1999)\end{array}$ & $\begin{array}{l}\text { Y/X ratio } \\
(2001-2004)\end{array}$ & $\begin{array}{l}\text { Y/X ratio } \\
(2005-2008)\end{array}$ \\
\hline 1. Blood pressure device & 3.13 & 6.66 & 2.38 \\
2. Spectrophotometer & 4.00 & 5.55 & 3.33 \\
3. Electric suction unit & 2.85 & 6.66 & 2.38 \\
4. Electrocardio-graph & 2.38 & 4.00 & 2.25 \\
5. X-ray apparatus & 2.12 & 3.13 & 2.22 \\
6. Hot air sterilizer & 2.38 & 2.63 & 2.38 \\
7. Autoclave & 2.22 & 5.00 & 2.38 \\
8. Ventilator & 2.85 & 4.00 & 2.63 \\
9. Anaesthesia system & 3.33 & 4.34 & 2.85 \\
10.Blood bank refrigerator & 2.32 & 3.03 & 2.08 \\
Arithmetic mean of the three ratios $=$ & $\mathbf{2 . 7 5}$ & $\mathbf{4 . 5 0}$ & 2.48 \\
\hline
\end{tabular}

Table 5. Trend of the [MoH device acquisition price/Ad hoc device reference prices] ratio during the three periods of years: 1998-1999; 2000-2004 and 2005-2008.

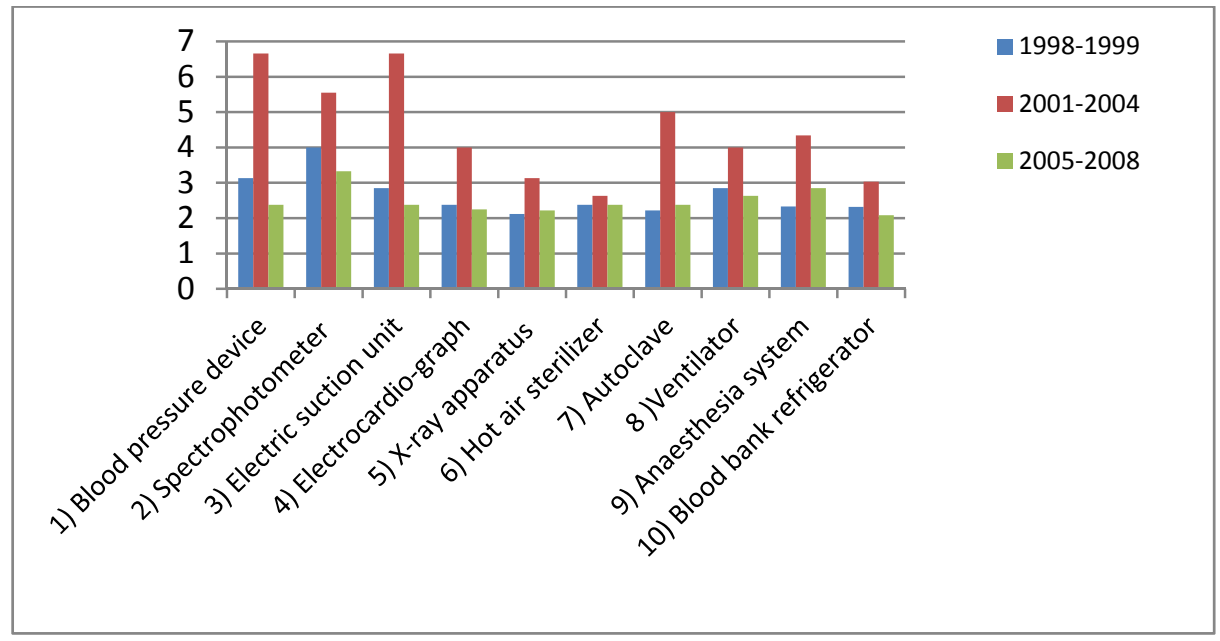

Fig. 2. Comparative graphs of the $\mathrm{MoH}$ selected medical device acquisition prices during the three periods of years:1998-1999; 2001-2004 and 2005-2008.

\subsection{Finding of the surveys 1 and 2}

1. Management and maintenance of healthcare technology

2. Healthcare technology assessment in the southern Benin public health facilities. 


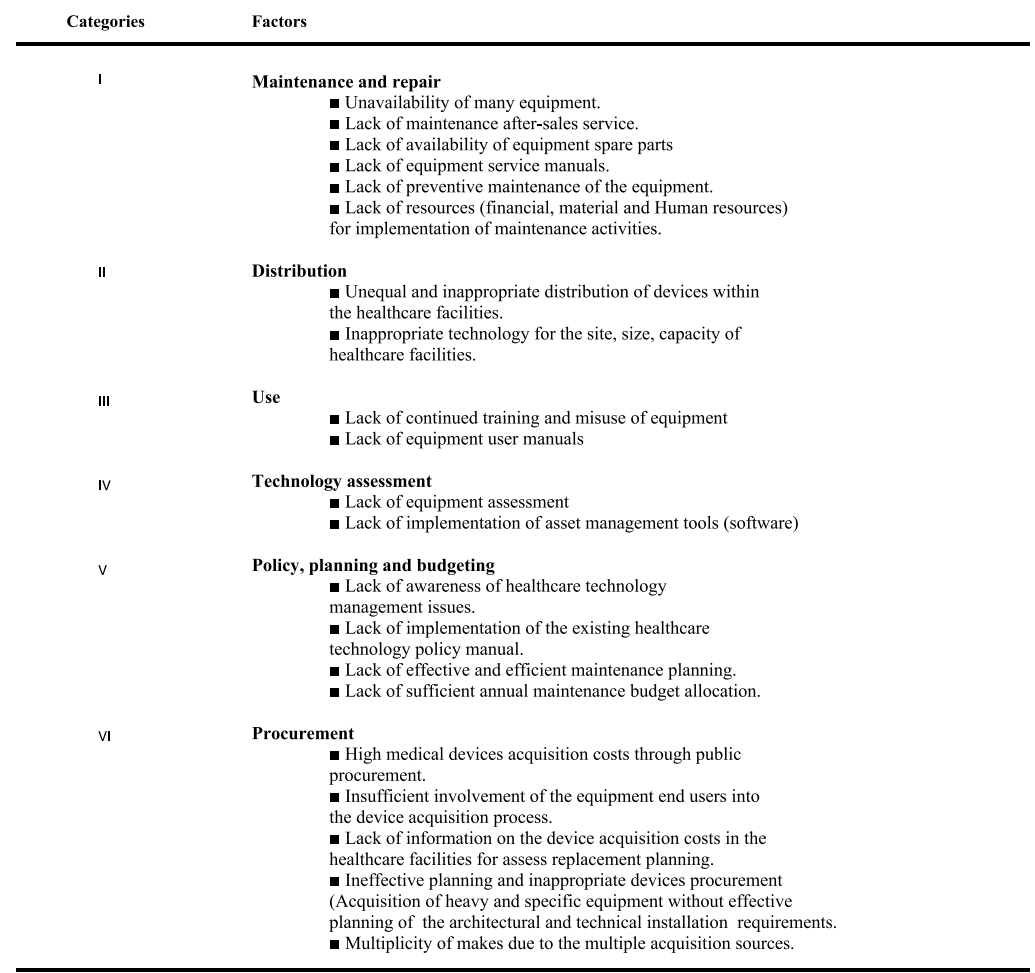

Table 6. Factors affecting the healthcare technology management cycle in 321 health centers and hospitals in southern Benin.

\section{Discussion and recommendations}

Goods acquisition, especially healthcare technology, represents an important part of any health budget and need to be looked with close attention. Through the results shown in Tables 2, 3, 4, 5 and, figure 2, it is clearly seen that, independently of the procurement years, the device acquisition prices by the $\mathrm{MoH}$ remain higher than the private healthcare facilities same device acquisition prices. Although the Benin first Goods and Services Procurement Code was implemented during the years 2001 to 2004 and has also been amended in 2004 and be implemented from 2005 to 2008 , no significant improvements were found regarding the higher prices of medical equipment paid by the $\mathrm{MoH}$. One can notice that the $\mathrm{MoH}$ pays too much for medical devices acquisition through public procurement and this was at its worst in 2001-2004. When analysing year by year available data of this period it was found that the highest acquisition prices were critical in 2003 and 2004. It is important to deeply understand the real reasons that underlie this phenomenon. Many hypotheses could be drawn to explain this fact but, it will be more interesting to increase the sample size $(>10$ medical devices) of the study for more reliability. The internal and external validities of the findings could be improved if a quasi-experimental study was designed. Thus, widely surveys will be conducted in the next papers with more representative sample size and strong method as controlled interrupted time series based on segmented regression analysis 
to infirm or to confirm the present findings and also to understand the true reasons of the ineffective management of healthcare equipment in Benin.

The Ministry of Health still needs a national public procurement policy and management tool like a reference prices list of the most widely used devices to overcome and to master the increasing and unreasonable medical device prices. It is normal to have the device acquisition costs paid by the government a bit higher than the reference set prices because of financial and administrative fees involved when the suppliers submit tenders. It is acceptable and reasonable to have the average device selling prices comprised between $\mathbf{1 . 1}$ to 1.2 times higher than the ad hoc reference prices. But, when the device selling prices offers by a supplier are more than that, they could be considered as outbidding. It is thus urgent for the Benin government especially the $\mathrm{MoH}$ to have an insight on that fact, to encourage the development of policies and laws regarding a reference price lists document of medical devices. The availability of the reference prices of the essential medical devices will allow the health sector authorities to monitor the usual financial diversion occurring during the procurement management activities. It is expected that once this document becomes available, the $\mathrm{MoH}$ could buy value-based pricing equipment each year and save a lot of money that can be used to improve the health of Benin population through other investments.

The results of the two surveys: i) "management and maintenance of healthcare technology" and ii) "healthcare technology assessment in the southern Benin public healthcare facilities" have revealed many weaknesses in the Benin health system through its healthcare technology management cycle. The results show failures in each link of the cycle (planning, budgeting, selection, procurement, distribution, installation, training, operation, maintenance and disposal of medical devices) resulting in low overall community health effectiveness. It is necessary to point out that the findings of the two surveys, i.e. the factors affecting healthcare technology management were only grouped (but not ranked) in sixth categories. The ranking of the factor categories (I, II, III, IV, V and VI) in order to set up priority actions will be discussed in the next paper.

As recommendations, twenty actions need to be taken by the government to overcome this situation in order to achieve its goal to improve the quality of/and access to health services that taking into account the poor and indigent. It is thus urgent to develop and implement a good medical device national policy which can include the following: i)An improved national list of essential medical devices and equipment based on evidence from the studies; ii) A national policy and plan for medical devices; iii) A national functional regulation authority in medical device empowered with legislation; iv) A document on assessment of medical device needs; v) National regulations based on ISO standards or WHO specifications; vi) National procurement procedure; vii) National policy for acceptance of donations; viii) Negotiated pricing list of each item of equipment; ix) National guide for management and use of medical devices; $x$ ) An inventory of suppliers and medical in use; xi) The cost of all the equipment of each level of Benin health facility related to the cost of infrastructure; xii) The service life span of each medical device or equipment in use in Benin health care facility or hospital in order to plan the replacement at a systematic time; xiii) The list of medical devices which have the highest risk; xiv) The spare parts which have the highest failure rate in order to plan their procurement; $x v$ ) The list of critical equipment and instrument affected by the electrical power outages and power anomalies in Benin hospitals; xvi) Good software based planning and management tools for management and 
maintenance of medical devices; xvii) A post-market surveillance/vigilance system for alerts, notifications and recalls; xviii) A national budget for devices, using costing, budgeting and financing; xix) Standard operating procedures and best practices that cover every stage in the life span of medical devices; $x x$ ) Creation of an independent Direction of Healthcare Technology Management and maintenance within the Ministry of Health.

The following Healthcare Technology Management Cycle (Figure 3) could be used as a framework for health equipment management in developing country, providing a guideline for the necessary regulations and systems.

The Healthcare Technology Management Cycle ${ }^{11}$ :An example of a framework for health equipment management in developing country.

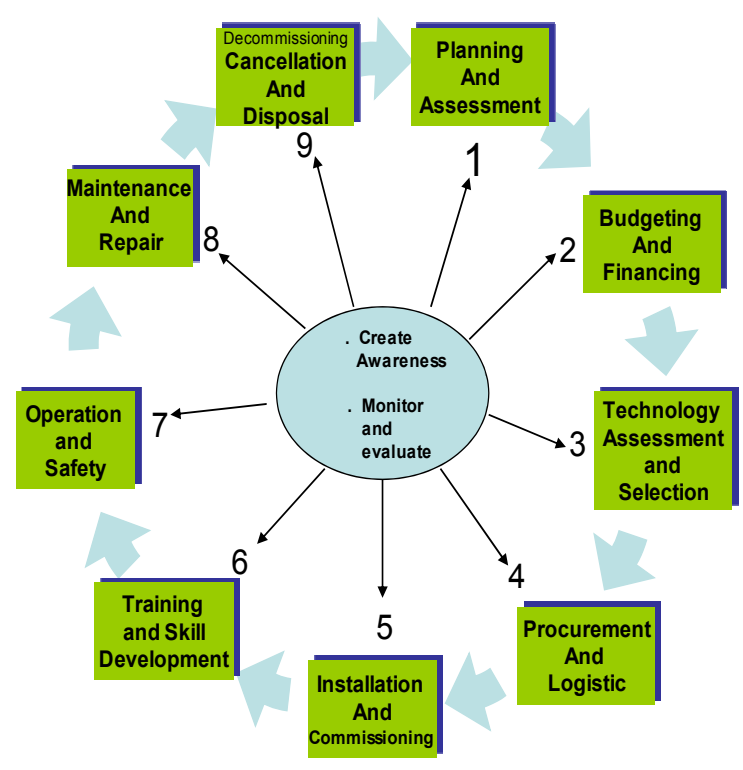

Fig. 3. The Healthcare Technology Management Cycle

\section{Conclusion}

Management and maintenance of healthcare technology in developing countries especially in the poor sub-Saharan Africa countries, remain a challenge. From the planning to the disposal of the devices many actions need to be undertaken to improve the Healthcare Technology Management Cycle. The achievements in the public healthcare sector depend on the full involvement of each stakeholder, but the main responsibility is still that of the governments. They need the political willingness and commitment to recognize management and maintenance of devices as an integral part of public health policy in order improve the quality and access to healthcare in each country. 


\section{Acknowledgement}

We would like to thank very much The Netherlands Organization for International Cooperation in Higher Education (NUFFIC) that grants fellowship for the main investigator to undertake $\mathrm{PhD}$ research. Thanks are also due to the technical officers of the Ministry of Health for their collaboration. The authors are grateful to Prof E. P. Wright for her fruitful comments.

\section{References}

[1] Bloom, G., Temple-Bird, C.: Medical Equipment in Sub-Saharan Africa: A Framework for Policy-Formulation. IDS research Report No.19, WHO/SHS/NHP/90.6, WHO, Geneva, 1990.

[2] Benin Tourisme: Benin; histoire [online]. 2007 Aug 25 Available from: URL: www.benintourisme. com.

[3] Department of Health, Republic of South Africa: A Framework for Health Technology Policies.

[4] Fahlgren B.: Access to effective medical technology in Developing Countries-what role for WHO? WHO Geneva 2004.

[5] Goodman, C.S. and Ahn, R.: Methodological Approaches Used in Health care Technology Assessment. NICHSR, USA 2004.

[6] Gouvernement du Benin. Développement économique Available from: URL: www.gouv.bj.

[7] Guinand C.: Maintenance biomédicale. Zones sanitaires appuyées par le PBA-SSP. Evaluation et suivi des activités des techniciens. Décembre 2000. Cotonou, 2000.

[8] Heimann, P., Poluta, M.A.: Health Technology Management in Sub-Saharan Region as a Prerequisite for Optimising the Donor Aid Intervention Process. (In press) WHO, ARA, Geneva, 1997.

[9] Institut National pour les Statistique et L'analyse Economique : Enquête Démographique et de Santé, Cotonou 2006.

[10] Issakovov, A.: Service and Maintenance in Developing Countries, pp. 21-28 in: Medical Devices: International Perspectives on Health and Safety. Ed. Van Gruting C.W.D. Elsevier, Amsterdam, 1994.

[11] Keller J.P.JR., and Walker S.: Best Practices for Medical Technology Management: A U.S. Air Force-ECRI Collaboration: Advances in Patient Safety: Vol. 4. pp 45-55, USA, 2004.

[12] Ministère de la Santé: Annuaire des statistiques sanitaires de la République du Bénin. Edition 2006.

[13] Ministère de la Santé Publique: Atelier National d'Orientation des Politiques et Stratégies Nationales de Maintenance Hospitalière en République du Bénin à Possotomè du 21 au 23 février 2000 . Possotomè 2000.

[14] Ministère de la Santé Publique de la République du Bénin : Avant-projet de politique et stratégies de maintenance des infrastructures et équipements médicaux au Bénin, Février 2000. Possotomè 2000.

[15] Ministère de la Santé de la République du Bénin: Etude d'évaluation de la situation actualisée des plateaux techniques des formations sanitaires publiques par niveau de soin et vérification de leur conformité aux normes dans les six (06) départements du sud Bénin, Bénin 2006. 
[16] Ministère de la Santé Publique de la République du Bénin : Etude sur l'élaboration d'un système décentralisé de maintenance hospitalière (30 mars au 15 avril 1995). Cotonou 1995

[17] Ministère de la Santé de la République du Bénin: Politique de maintenance des infrastructures, des équipements médico-techniques et du parc automobile en République $d u$ Bénin. Cotonou 2002

[18] Ministère de la Santé Publique de la République du Bénin: Politiques et stratégies nationales de développement du secteur santé (1997-2001). Cotonou 1998.

[19] Ministère de la Santé Publique de la République du Bénin: Politiques et Stratégies Nationales de Maintenance Hospitalière en République du Bénin (2001-2005). Cotonou 2000.

[20] Ministère de la Santé de la République du Bénin: Rapport de la mission d'expertise thématique en gestion et maintenance des équipements et infrastructures de la santé, Bénin 2005

[21] Ministère de la Santé de la République du Bénin: Recueil d'informations de la Cellule de Passa-tion des Marchés, Cotonou, 2006.

[22] Projet Bénino-Allemand des Soins de Santé Primaire (PBA-SSP): Guide d'entretien du Matériel des CSSP et CCS du Projet Bénino-Allemand des Soins de Santé Primaires. Cotonou 1997

[23] South African Medical Research Council: Executive Report of the Regional Workshop on Health care Technology in Sub-Saharan Region, Somerset West, South Africa. April 1994

[24] USAID : Rapid assessment of the health system in Benin. Benin 2002

[25] USAID: Country background; Benin. Available from: URL: www.usaid.gov.

[26] Wang, B.: A framework for Health Equipment Management in Developing Countries. Hospital Engineering and Facilities Management 2003

[27] World Health Organization: Medical Device Regulations: Global Overview and Regulating Principle. WHO, ISBN 924154618.

[28] World Health Organization: Regulation Challenges (Medical device regulation: a framework). WHO Drug Information Vol 17, No. 4, 2003.

[29] World Health Organization: Experts on Healthcare Technology in the Developing World Meet at Savoy Place (Managing Health care Technology) WHO. 2, 2002.

[30] World Health Organization: Essential Health Technologies: Strategy 2004- 2007. WHO. Draft for comments by member States. 11, 2003.

[31] World Health Organization.: Global Harmonization Task Force (Working Toward Harmonization in Medical Device Regulation Full Document). Geneva 2004. 


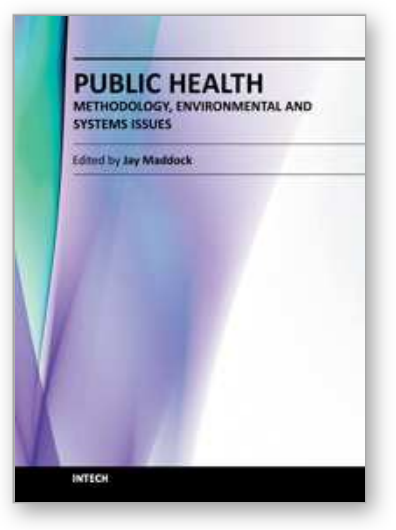

\author{
Public Health - Methodology, Environmental and Systems Issues \\ Edited by Prof. Jay Maddock
}

ISBN 978-953-51-0641-8

Hard cover, 432 pages

Publisher InTech

Published online 30, May, 2012

Published in print edition May, 2012

Public health can be thought of as a series of complex systems. Many things that individual living in high income countries take for granted like the control of infectious disease, clean, potable water, low infant mortality rates require a high functioning systems comprised of numerous actors, locations and interactions to work. Many people only notice public health when that system fails. This book explores several systems in public health including aspects of the food system, health care system and emerging issues including waste minimization in nanosilver. Several chapters address global health concerns including non-communicable disease prevention, poverty and health-longevity medicine. The book also presents several novel methodologies for better modeling and assessment of essential public health issues.

\title{
How to reference
}

In order to correctly reference this scholarly work, feel free to copy and paste the following:

P. Th. Houngbo, G. J. v. d. Wilt, D. Medenou, L. Y. Dakpanon, J. Bunders and J. Ruitenberg (2012). Policy and Management of Medical Devices for the Public Health Care Sector in Benin, Public Health - Methodology, Environmental and Systems Issues, Prof. Jay Maddock (Ed.), ISBN: 978-953-51-0641-8, InTech, Available from: http://www.intechopen.com/books/public-health-methodology-environmental-and-systems-issues/policyand-management-of-medical-devices-for-the-public-health-care-sector-in-benin

\section{INTECH}

open science | open minds

\author{
InTech Europe \\ University Campus STeP Ri \\ Slavka Krautzeka 83/A \\ 51000 Rijeka, Croatia \\ Phone: +385 (51) 770447 \\ Fax: +385 (51) 686166 \\ www.intechopen.com
}

\author{
InTech China \\ Unit 405, Office Block, Hotel Equatorial Shanghai \\ No.65, Yan An Road (West), Shanghai, 200040, China \\ 中国上海市延安西路65号上海国际贵都大饭店办公楼 405 单元 \\ Phone: +86-21-62489820 \\ Fax: +86-21-62489821
}


(C) 2012 The Author(s). Licensee IntechOpen. This is an open access article distributed under the terms of the Creative Commons Attribution 3.0 License, which permits unrestricted use, distribution, and reproduction in any medium, provided the original work is properly cited. 